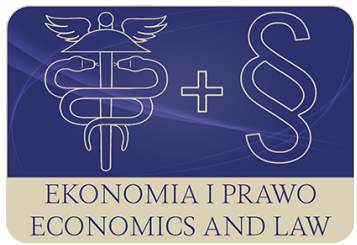

EKONOMIA I PRAWO. ECONOMICS AND LAW

Volume 18, Issue 4, December 2019

p-ISSN 1898-2255, e-ISSN 2392-1625

www.economicsandlaw.pl

EKONOMIA I PRAWO
ECONOMICS AND LAW

ORIGINAL ARTICLE

received 15.09.2019; revised 07.12.2019; accepted 31.12.2019

Citation: Bejger, S. (2019). Wholesale fuel price adjustment in Poland: examination of competitive performance. Ekonomia i Prawo. Economics and Law, 18(4): 385-412. doi:10.12775/EiP.2019.026.

\title{
Wholesale fuel price adjustment in Poland: examination of competitive performance
}

\author{
SYLWESTER BEJGER \\ Nicolaus Copernicus University in Torun, Faculty of Economic Sciences and Management, \\ Department of Applied Informatics and Mathematics in Economics, \\ ul. Gagarina 13a, 87-100 Toruń, Poland \\ ఐ sylw@umk.pl \\ orcid.org/0000-0001-7900-946X
}

\begin{abstract}
Motivation: Import parity pricing, potentially provoking parallel pricing, and asymmetric price transmission are both considered as the factors that can distort competitiveness and foster collusive behavior on the fuel markets.

Aim: The study encompass an analysis of usual 'rocket and feathers' reactions in response to common drivers of the gasoline wholesale price and comparative analysis of individual

players' pricing paths in order to examine competitive performance of the market. To account for an implied IPP pricing mechanism, a set of common wholesale price determinants was expanded.

Results: We revealed a significant short-run asymmetries in a transmission of all downstream price determinants and shown that the foreign exchange rate is a main driver underlying a positive asymmetry in the wholesale prices' paths. We compared dynamic price adjustment paths for the major players and revealed the common patterns. That suggest a strong possibility of parallel pricing.
\end{abstract}

Keywords: market competition; asymmetric price adjustment; individual players' pricing mechanism; nonlinear econometric models

JEL: D43; L1; L7; Q4; C2 


\section{Introduction}

Asymmetries in the adjustment of downstream prices to up-stream price changes have extensively been investigated using different empirical models in a wide range of commodity markets (Frey \& Manera, 2007; Karagiannis et al., 2015; Meyer \& Cramon Taubadel, 2004). The asymmetric pass through (APT) of different shocks at a macro or a micro economic level is obviously not limited to liquid fuel markets, but it was the study of Bacon (1991) focusing on such market that started a wide-spread discussion on the "rockets and feathers' phenomenon in observable price series. Peltzman (2000), analyzed 165 producer goods and 77 consumer goods and concluded that the rockets and feathers pattern could be found in two thirds of these markets. From a point of view of the European competition legislation ${ }^{1}$ APT can be seen as a sign of potential anticompetitive horizontal practices, namely exploitation of market power and a tacit collusion. Those practices are frequently connected with another 'circumstantial evidence' 2 of concerted practice ${ }^{3}$ which is parallel pricing. This paper definitely fits into the stream of competition studies on strategic behavior of the players in the oligopolistic industries and markets with an adequate policy implications. This study, however, differs significantly from other relevant works in this field, because:

- it is the first approach focusing on a comparative examination of the APT for the individual market players;

- the analysis concerns not only the usual pass-through from crude oil price to product prices, but we also included the pass-through of domestic currency exchange rate fluctuations, as in Bagnai \& Ospina (2015) or Greenwood-Nimmo \& Shin (2013), and other possible wholesale price determinants (a spot price of a reference product and prices of futures contracts), as implied by the Import Parity Pricing (the IPP) schema of the wholesale price determination.

There are some qualitative evidences that IPP schema for establishing a wholesale price is presumably used by the two major players in the Polish market, PKN Orlen and LOTOS (Bejger, 2015a, pp. 88-89). Competition Authorities' reports states that the use of the IPP formula to set domestic refinery prices, in particular in buy-sell agreements, has implications for road fuel pricing along the supply chain and may lessen competition in wholesale gasoline markets, limiting effective price competition between refiners (Australian Competition and Consumer Commission, 2007, pp. 12,126; Bundeskartellamt,

${ }^{1}$ For the European (and Polish) competition legislation leading role plays the Treaty on the Functioning of the European Union (2012). Competition rules are set out in Articles 101-106 of the treaty.

2 For a notion of concerted practice in the EU, see Judgments of the European Court (1972, 1975, 1993).

3 For the comprehensive overview of legal and economic understanding of various horizontal anticompetitvie practices see Bejger (2016b). 
2009, pp. 25-30). The benchmark price could also take a role of focal price, as was shown by Bejger (2016a) and Faber \& Janssen (2019) fostering parallel pricing on the market. By expanding the scope of the research we were able to formulate the following, specific research tasks, on which we focused in our analyses:

- modelling pricing behaviour of the players accounting for long-term and short-term APT, by using an appropriate econometric approach (NARDL model specification);

- assessing possibility of parallel pricing by comparing of pass-through patterns of two major players in response to shifts in crude oil prices and the exchange rate level;

- uncovering IPP schemas of pricing by comparing pass-through patterns of two major players in response to shifts in potential 'price creators' a spot gasoline price and gasoline futures;

- discussing the results, especially shapes of adjustment paths of the players and their implications for a potential competition's distortions.

\section{Literature review}

The studies focusing on price paths of gasoline and motor diesel oil at the retail and the wholesale market levels seem to be of special importance for the competition authorities because of a coincidence of two factors: mass character of a product and a potential harm to the competitiveness of markets. A positive APT implies a possibility of both 'unfair' redistribution and a net welfare loss, which is connected with the pattern or the amount asymmetry. On a wholesale level of a supply chain, which is under consideration in our study, one of the possible explanations for the phenomenon of a positive APT (or 'downward sticky' aka 'rockets and feathers' prices) is a significant market power of the players in the concentrated and imperfectly competitive industry ${ }^{4}$. Borenstein et al. (1997, pp. 328-335), Radchenko (2005), and the meta study by Perdiguero-García (2013) support this claim. Other studies on wholesale level do not support APT, e.g. Bachmeier \& Griffin (2003, pp. 773-774). APT is not an anticompetitive practice per se. However, when a possible strategic mechanism behind oligopolistic competition is recalled, explained by game theory models of tacit collusion (starting with Friedman's (1971) seminal work on supergames, and Maskin \& Tirole (1988) models), accompanied by some kind of 'suspicious behavior', such situation may lead to a strong public pressure on competition authorities to screen domestics fuel markets and refining industries, and formulate certain competition recommendations towards them. Sector inquiries on oil refineries and petroleum wholesale markets by the competition authori-

${ }^{4}$ An alternative explanation of APT is available, namely: customer's search costs (retail markets), asymmetric short-run costs of changes in inventories, and asymmetric valuation of inventories enhanced by FIFO accounting, e.g. Balke et al. (1998), Borenstein (1991), Borenstein \& Shepard (2002), Johnson (2002), Kaufmann \& Laskowski (2005). 
ties are an evidence of such attitude. The Australian Competition and Consumer Commission report (2007), the Pöyry Energy Consulting report (2009), Bundeskartellamt reports $(2009,2011)$, the Final Report on the analysis of the liquid fuel and bottled gas sectors in Portugal, prepared by the Portuguese Competition Authority (2009) and a summary of the policy round table, OECD (2013) can be mentioned here. There are only a few previous studies concerning the pricing in the Polish wholesale fuel market. In Bejger \& Bruzda (2002), the authors attempted to determine whether an APT can be identified in the Polish wholesale gasoline and diesel motor oil price data from the dominant player, PKN Orlen. Other studies on this market are: Leszkiewicz-Kędzior (2011), Leszkiewicz-Kędzior \& Welfe (2014) and Miłobędzki (2008), however only Bejger \& Bruzda (2002) research was done in a context of competition studies. The NARDL approach we applied was used in a context of APT research previously, e.g. Atil et al. (2014), Bagnai \& Ospina (2015), Chattopadhyay \& Mitra (2015), Greenwood-Nimmo \& Shin (2013), with a very promising results.

\section{Methods}

This section provides a specification of theoretical model used in research, description of data sample and empirical specification forming a research hypothesis for examination of prices pass-through.

\subsection{General model specification}

The phenomenon under examination is connected with inherently dynamic processes, though we focused on dynamic models only. Two kinds of possible asymmetric pass-through need to be taken into account: the magnitude asymmetry, in which the amount of downward price change differs depending on a direction of the upstream price change, mainly interesting in the long-run horizon, and the pattern asymmetry, in which the speed of the downward price change differs depending on a direction of the upstream price change, mainly interesting in the short-run horizon. Existing literature points to three most common specifications of the asymmetric dynamic relationship: an asymmetric ECM (Granger \& Lee, 1989), an autoregressive threshold ECM (TAR-ECM) (Hansen, 2000), and ECM with threshold cointegration (M-TAR) (Enders \& Granger, 1998). We focused on the nonlinear autoregressive distributed lag (NARDL) approach, proposed by Shin et al. (2013, pp. 11-14). It uses a nonlinear auto-regressive distributed-lag (NARDL) model, of a structure derived from the ARDL $(p, q)$ model (Pesaran \& Shin, 1999; Pesaran et al., 2001). In the most popular modeling structures listed above, asymmetry is allowed only in the adjustment parameters (short-run elasticities and an error correction parameter), and explicitly not in the long-run elasticities. If the underlying long-run relation has asymmetric parameters, a symmetric specification may lead to biased estimates, thus compromising the reliability of the long- and short-run parameters 
estimates. An NARDL unrestricted specification and bound testing of cointegration in a context of asymmetry have many desirable features. It allows for asymmetries in both the short- and long-run parameters. A one-step estimation of the complementary ECM is likely to improve the model performance for small samples, particularly in terms of the power of the cointegration tests (Shin et al., 2013). The ability to simultaneously estimate both long and short-run asymmetries is a very flexible approach and provides straightforward means for testing both long and short-run symmetry restrictions.

The NARDL $(p, q)$ in-levels model (Shin et al., 2013, p. 11) can be expressed as follows:

$$
y_{t}=\alpha_{o}+\sum_{j=1}^{p} \Phi_{j} y_{t-j}+\sum_{j=o}^{q}\left(\boldsymbol{\Theta}_{j}^{+{ }^{\prime}} \boldsymbol{x}_{t-j}^{+}+\boldsymbol{\Theta}_{j}^{-{ }^{\prime}} \boldsymbol{x}_{t-j}^{-}\right)+\varepsilon_{t},
$$

where: $y_{t}$ is a scalar dependent variable, $\boldsymbol{x}_{t}$ is a $k \times 1$ vector of regressors decomposed as: $\boldsymbol{x}_{t}=\boldsymbol{x}_{0}+\boldsymbol{x}_{t}^{+}+\boldsymbol{x}_{t}^{-}, \Phi_{j}$ 's are the autoregressive parameters, $\boldsymbol{\Phi}_{j}^{+}$ and $\boldsymbol{\Phi}_{j}^{-}$are the asymmetric distributed lag parameters, and $\varepsilon_{t}$ is an iid process with a zero mean and constant variance $\sigma_{\varepsilon}^{2}$.

The key role in asymmetry examination is played by a so-called conditional error correction form (conditional ECM, sometimes called CECM, see: Pesaran et al. (2001), Shin et al. (2013, p. 13):

$$
\begin{aligned}
& \Delta y_{t}=\rho \xi_{t-1}+\sum_{j=1}^{p-1} \gamma_{j} \Delta y_{t-j}+\sum_{j=0}^{q-1}\left(\boldsymbol{\pi}_{j}^{+^{\prime}} \Delta \boldsymbol{x}_{t-j}^{+}+\boldsymbol{\pi}_{j}^{-{ }^{\prime}} \Delta \boldsymbol{x}_{t-j}^{-}\right)+\varepsilon_{t}= \\
& =\rho y_{t-1}+\boldsymbol{\Theta}^{+{ }^{\prime}} \boldsymbol{x}_{t-1}^{+}+\boldsymbol{\Theta}^{-{ }^{\prime} \boldsymbol{x}_{t-1}^{-}}+\sum_{j=1}^{p-1} \gamma_{j} \Delta y_{t-j}+ \\
& +\sum_{j=0}^{q-1}\left(\boldsymbol{\pi}_{j}^{+\prime} \Delta \boldsymbol{x}_{t-j}^{+}+\boldsymbol{\pi}_{j}^{-\prime} \Delta \boldsymbol{x}_{t-j}^{-}\right)+\varepsilon_{t},
\end{aligned}
$$

where: $\xi_{t}=y_{t}-\boldsymbol{\beta}^{+} \boldsymbol{x}_{t}^{+}+\boldsymbol{\beta}^{-} \boldsymbol{x}_{t}^{-}$is the nonlinear error correction term, where $\boldsymbol{\beta}^{+}=-\boldsymbol{\Theta}^{+} / \rho$ and $\boldsymbol{\beta}^{-}=-\boldsymbol{\Theta}^{-} / \rho$ are the asymmetric long-run parameters (long-run multipliers), parameters capture short-run asymmetries, $\boldsymbol{\pi}_{i}^{+}$and $\boldsymbol{\pi}_{i}^{-}$ is an error correction coefficient.

\subsection{Statistical testing and inference based on CECM}

In the APT examinations a statistical inference based on CECM (2) creates a pipeline of sets and tests of hypotheses, from the most general hypothesis of cointegration existence to detailed tests of symmetry restrictions.

1. (A) Tests for cointegration (long-run relationship). Two tests for the existence of a stable long-run levels relationship may be used:

- (Al) The $\mathrm{t}_{\mathrm{BDM}^{-}}$-statistic proposed by Banerjee et al. (1998, pp. 270-280);

- (A2) The ${ }_{\mathrm{FPsS}}$-statistics by Pesaran et al. (2001, pp. 297-304).

2. (B) Tests for asymmetry. The NARDL model described by equation (2) allows for three general forms of asymmetry:

- (B1) long-run amount or 'reaction asymmetry', associated with $\boldsymbol{\beta}^{+} \neq \boldsymbol{\beta}^{+}$; 
- (B2) short-run amount or 'impact asymmetry', associated with the inequality of the coefficients on the contemporaneous first differences $\Delta x_{t}^{+}$ and $\Delta x_{t}^{-}$;

- (B3) speed asymmetry or 'adjustment asymmetry' captured by the patterns of adjustment from the initial equilibrium to a new equilibrium following an economic perturbation (i.e. the dynamic multipliers). Adjustment asymmetry derives from an interaction between impact and reaction asymmetries in conjunction with the error correction coefficient.

All symmetry restrictions (both long- and short-run) can be tested by the standard Wald test.

Speed asymmetry (B3) could be inferred from NARDL on a basis of the calculation of dynamic multipliers. The dynamic multipliers provide explainable and intuitive means for assessing the path between the short- and long-run which clarifies the nature of the dynamic adjustment. This property is in line with Bejger (2015b, p. 288), where he postulates that visualization should be used as an 'economic background' of anticompetitive cases not only in well known, quasi-experimental methods framework, including in particular the Difference in Difference method often used in such a context (which do not reflect economic theory but are data-driven) but in a more sophisticated research, as well.

\subsection{Data and empirical specification}

The IPP pricing hypothesis which our study is testing for is based on the assumption that fuel for road use is a tradable good and the ex-refinery price depends not as much on the crude price and the costs of refining at domestic refineries, but rather on a price that a purchaser has to pay for this product in a ARA hub plus transport costs and other relevant spreads for the selected storage site. Therefore, theoretically the IPP is the maximum level that can be reached by the domestic producers' wholesale price when there are no barriers to import. To define the IPP policy, two key components need to be specified: the formula itself and the reference (benchmark) price indices. The formula itself is basically common for different countries, describing a wholesale net price of a fuel product as a function of a reference price and certain other costs.

We decided to limit the scope of our research and examine reactions of wholesale gasoline prices at first, as this product has an important share in consumption, is less prone to substitution and illegal import (which is a serious problem in the case of motor diesel oil) and, which was an important reason, we were able to provide well-specified reference prices for it. The price of Brent crude oil and the exchange rate were assumed as important upstream (wholesale) price determinants. The spot gasoline price and futures contracts for gasoline were assumed as a reference prices to be possibly used in the IPP formula. As we had no access to a commercially available quotation for gasoline PRM UNL 10 ppm, published on a daily basis by one of the Price Reporting Agencies (e.g. Platts or Argus Media) for transactions carried out with refineries in North West- 
ern Europe (NWE) ARA hub, (which would probably be the most appropriate as a benchmark price in the Polish market), we used the NYH gasoline spot price instead. This substitution is statistically correct for an APT examination if we take into account the (Energy Information Administration, 2014) analysis which confirms stable and close relationship between ARA and NYH spot gasoline prices.

The sample period is 01.01.2006-31.12.2016. The set of raw data before preprocessing consisted of:

- wholesale prices of standard EU95 gasoline (without VAT), published by two major players in a Polish market, LOTOS and PKN Orlen (PKN in short). The series are published on the players' websites; the original series included excise tax and fuel surcharge, in Polish złoty (currency code - PLN) per $1 \mathrm{~m}^{3}(1000 \mathrm{~L})$;

- USD/PLN average exchange rate, published by the National Bank of Poland $(\text { table A })^{5}$;

- Brent crude oil spot price, published by EIA, in USD per barrel;

- New York Harbor Regular Gasoline spot price, published by EIA, in USD per gallon;

- New York Harbor Reformulated RBOB Regular Gasoline Future Contracts 1 to 4, published by EIA, in USD per gallon.

All of these series contain irregular daily data. We deliberately decided to model at a high frequency, because of a nature of the observed price mechanism in the domestic market, as described in Bejger (2015a, pp. 91-92). Additionally, we wanted to fully utilize unique, individual players' daily price series, rarely used in the literature of a subject. After preprocessing we obtained the set of variables. Dependent variables included: $l w_{-} p \_n$ (log of the wholesale price of unleaded standard 95 octane gasoline reported by PKN, in PLN/ $\mathrm{m}^{3}$, excluding the excise tax and the fuel duty), and $l w \_l \_n$ (log of the wholesale price of unleaded standard 95 octane gasoline reported by LOTOS, in PLN/ $\mathrm{m}^{3}$, excluding the excise tax and the fuel duty). Independent variables included: lus_x (log of the PLN/USD average exchange rate), $l b \_s$ (log of the Brent crude oil spot price, in USD $/ \mathrm{m}^{3}$ ), lnyh_s (log of New York Harbor Regular Gasoline spot price, in USD $/ \mathrm{m}^{3}$ ), and lf_l, lf_2, lf_3, lf_4 (log of New York Harbor Reformulated RBOB Regular Gasoline Future Contracts 1 to 4, in USD per $\left.\mathrm{m}^{3}\right)$. All of the series were monitored on a daily basis during a five-day (Monday-Friday) working week. Our main research assumption considers empirical model of a general form: wholesale price of gasoline for player $i=f$ (USD/PLN exchange rate, upstream price), where $i \in\{$ LOTOS, PKN $\}$.

As we have 2 players and 6 upstream prices, there are 12 specific passthrough models to examine, each consisting of an independent variable and two regressors. To reach our primary research goal and demonstrate possible long-

5 The exchange rate is a measure of a price of US dollar expressed in Polish domestic currency PLN, and its increase denotes a US dollar appreciation/PLN depreciation, and vice versa. 
and short-run asymmetries in wholesale price reactions to the exchange rate and quotation price shocks, we used the NARDL model and the bound testing approach to cointegration. A general testable specification derived from (2) had the following form:

$$
\begin{aligned}
& \Delta y_{t}=\text { const }+ \text { break }+\rho y_{t-1}+\Theta_{u}^{+} u s_{t-1}^{+}+\Theta_{u}^{-} u s_{t-1}^{-}+\Theta_{x}^{+} x_{t-1}^{+}+ \\
& +\Theta_{x}^{-} x_{t-1}^{-}+\sum_{j=1}^{p-1} \gamma_{j} \Delta y_{t-j}+\sum_{j=o}^{q-1}\left(\pi_{u j}^{+} \Delta u s_{t-1}^{+}+\pi_{u j}^{-} \Delta u s_{t-1}^{-}+\right. \\
& \left.+\pi_{x j}^{+} \Delta x_{t-1}^{+}+\pi_{x j}^{-} \Delta x_{t-1}^{-}\right)+\varepsilon_{t},
\end{aligned}
$$

where: $y_{t}=l w_{-} p_{-} n$; $l w_{-} l \_n$ (downstream prices), $u s_{t}=l u s_{-} x$ (an important price determinant), $x_{t}=l b_{-} s ; \ln y h_{-} s ;$ lf_l; lf_2; lf_3; lf_4 (upstream prices), break - a dummy variable, where the variable assumes a value of 1 on each of the days following 12/31/2014. Additionally, we should remember that $\beta_{u}^{+}=-\Theta_{u}^{+} / \rho, \beta_{u}^{-}=-\Theta_{u}^{-} / \rho, \beta_{x}^{+}=-\Theta_{x}^{+} / \rho$, and $\beta_{x}^{-}=-\Theta_{x}^{-} / \rho$ are the assymetric long-run parameters, $\pi_{u j}^{+}, \pi_{u j}^{-}$, $\pi_{x j}^{+}, \pi_{x j}^{-}$parameters capture short-run assymetries, especially $\pi_{u 0}^{+}, \pi_{u 0}^{-}, \pi_{x 0}^{+}, \pi_{x o}^{-}$are the impact parameters, and $\rho$ is an error correction coefficient.

\section{Results}

The key characteristics of the Polish refining industry, the wholesale market for liquid fuels, the players, and the price creation mechanisms were isolated and studied extensively in Bejger (2015a). We summarize here the most important economic factors for the last year of the sample period, referring to chart 1 and chart 2. We can state that at the wholesale level the Polish liquid fuel market is a duopolistic market with two major players. The refining industry and the wholesale market are highly concentrated. There exist capacity constraints for domestic production and the entry barriers are high due to the logistic infrastructure and regulations. The most important refined products are homogenous motor fuels (unbranded diesel oil for road transport (10 ppm Sulphur), and unbranded unleaded 95 octane gasoline (10 ppm Sulphur). Table 1 contains descriptive statistics of the time series we examine. It shows that empirical distributions are moderately negatively skewed, the assumption of distribution normality is rejected in all cases, and wholesale prices distributions have very similar moments which differ from rest of the series. For obvious reasons, the futures series exhibits similar properties within its set. To conduct a research properly we had to ensure that all variables are integrated of order l, or I(l) at most, as this step was necessary and important for NARDL approach. Using the usual unit root tests - the Augmented Dickey-Fuller (ADF) and the Kwiatkowski-Phillips-Schmidt-Shin (KPSS) we check the stationarity and the order of integration for the variables. Tables 2 and 3 show a summary of the tests' results. From the results we concluded that each of the series must be either I $(0)$ or I(l). The sample period under consideration was characterized by several pe- 
riods of crises (including the 2008 financial crisis), and other important financial and geopolitical issues. For that reason we conducted an examination of unit root test with structural breaks Perron (1989), with the same conclusion. All of the obtained results indicate that all time series are I(l) and the null hypothesis of integration of higher order is rejected; thus the preliminary requirement of ARDL and NARDL models is fulfilled.

To obtain a base point against which we can evaluate the possible asymmetric reactions of downstream prices, we first estimated a symmetric $\operatorname{ARDL}(p, q, q)$ for all possible empirical specifications ${ }^{6}$. In all cases, $t_{B D M}$ and $F_{\text {PSS }}$ statistics confirmed a long-run relationship. Examinations of the ARDL models showed that for future contracts $\mathrm{Fl}$ to F4, a gradual decrease in the model properties is observed, especially in terms of goodness of fit (adjusted $\mathrm{R}^{2}$ and information criterions AIC and $\mathrm{BIC}$ ). As the future contract Fl appeared to be the most informative (ARDL model showed the best fit with most significant parameters), we decided that further examination of contract F2 to F4 would be unnecessary and without important informative value. Therefore, in the remaining part of the study we focused on lus_x, lb_s; lnyh_s and lf_l regressors.

The main results of APT examination were obtained by estimation of the unrestricted NARDL model (3) with a maximum order of lags chosen on the basis of the AIC information criterion, for all possible empirical specifications ${ }^{7}$. The residuals were tested for a serial correlation, as the key assumption in the ARDL/ bounds testing methodology is that the errors of equation (3) must be serially independent. Table 4 presents the most important results of our research. Analyzing this table, we can see that in all cases the estimated value of the error correction coefficients, the asymmetric long-run parameters and the impact parameters (capturing the most direct short-run asymmetric transmission), are all significant at the $1 \%$ level. The values of statistics of tests (A1) and (A2) $\left(\mathrm{F}_{\mathrm{PSS}}\right.$ and $\mathrm{t}_{\mathrm{BDM}}$ ) allow us to reject the null hypothesis of non-cointegration in all cases. This finding implies that the USD/PLN exchange rate and the prices of Brent crude oil, NYH gasoline and future contract $\mathrm{Fl}$ are important drivers for wholesale gasoline prices in the Polish market in a long-run. For crude price passthrough, a long-run asymmetric coefficient of approximately 0.8 was found for both players, which indicates that wholesale consumers are fairly insulated from fluctuations in the crude oil market in the long-run. This observation is consistent with Borenstein et al. (1997, pp. 332-334) and Greenwood-Nimmo \&

${ }^{6}$ We followed the general-to-specific approach recommended by Shin et al. (2013) and selected the final ARDL specification for linear and nonlinear (asymmetric) versions. The estimated specification is chosen by starting with max $p=13$ max $q=13$ and selecting the optimal lag length using Akaike info criterion. These high values of $\mathrm{p}$ and $\mathrm{q}$ are necessary for daily data. Detailed results of estimation of ARDL's avaiable on request.

7 We estimated restricted versions of (3) with restrictions imposed on long- or shortrun parameters. In four cases, a full asymmetric NARDL model proved to be the best model specification in in terms of information criteria and adjusted $\mathrm{R}^{2}$. Two models with future contract price were slightly worse, taking into account these measures. 
Shin (2013, pp. 412-414). Interestingly, the exchange rate related to the crude price has far more influence over the long-run wholesale gasoline price level. $1 \%$ change in the USD/PLN exchange rate changes the wholesale gasoline price by about 1.1\%. Bagnai \& Ospina (2015, pp. 45-48) found a similar effect of the exchange rate in the Italian market. The speed of adjustment towards the long-run equilibrium is about $2 \%$. For the spot gasoline price, the long-run multipliers have similar values for both gasoline price and the exchange rate, and it does not exceed 0.9. The speed of adjustment to an equilibrium on one day is the fastest of all model specifications (the error correction parameter is about 0.05). For the future contract Fl, all long-run parameter estimates exceed 1 .

At the next step of statistical inference based on table 4 symmetry restrictions are analyzed. Case (Bl) was labelled as $w_{-} l r_{-} u$ (a test of restrictions imposed on long-run multipliers associated with positive and negative changes in the exchange rate) and $w_{-} l r_{-} x$ (a test of restrictions imposed on a long-run multipliers associated with positive and negative changes in the regressor $x$ ). Table 4 shows that for crude oil and gasoline $\beta_{u}^{+}>\beta_{u}^{-}$and $\beta_{x}^{+}>\beta_{x}^{-}$, and for future contracts these inequalities are reversed. However, the difference between long-run multipliers of negative and positive changes is statistically significant only for gasoline. Therefore, in a long run gasoline price reduction has a greater impact on wholesale prices than its increase, while the reaction of wholesale prices to depreciation of the Polish national currency is significantly stronger than to its appreciation. These results are similar to the findings of Bagnai \& Ospina (2015, pp. 45-46), where negative long-run asymmetry was found for crude and positive one for the exchange rate. Short run symmetry restrictions, characterized by (B2) group are presented in table 4 as: $w_{-} s r a \_u, w_{-} s r a \_x-$ additive symmetry (exchange rate, regressor $x$ ); $w_{-} s r i \_u, w_{-} s r i \_x$ - impact symmetry restriction (exchange rate, regressor $x$ ); $w_{-} s r p w_{-} x$ — pairwise symmetry (regressor $x$ only, as more important). Test results show clearly that the NARDL specification indicates important short-run differences in pass-through of positive and negative shocks in most of the cases. Table 5 presents the type of additive short-run asymmetry.

Taking the short-run asymmetric effects into account, it can be seen that an increase of $1 \%$ in the Brent crude prices entails an accumulative increase of $0.38 \%$ and $0.43 \%$ in wholesale gasoline prices, and that a decrease of $1 \%$ in crude prices leads to an accumulative decrease of $0.49 \%$ and $0.52 \%$ in wholesale gasoline prices. In that case impact asymmetry is also observed, although the direct (previous day) effect shows positive asymmetry. Negative asymmetry in cumulative short-run effect of the crude price change was found by Atil et al. (2014, pp. 569-570). In the case of transmission of the NYH gasoline price shocks, rejections of the null (symmetry) in the pairwise (NYH gasoline) and additive (both NYH gasoline and the exchange rate) short run restrictions are observed. Similarly, as in the case of the Brent crude, there is negative asymmetry in pass-through of the commodity price (NYH spot), but simultaneously, a strong positive asymmetry in pass-through of exchange rate changes is visible. 
In terms of absolute values, a raise in the wholesale price of gasoline is faster than its fall on a short-run (in an approximate period of one week) due to an impact of the national currency depreciation, as a $1 \%$ increase in the NYH gasoline price leads to an accumulative increase of 0.35 to $0.45 \%$ in wholesale gasoline prices, and a $1 \%$ decrease of the NYH gasoline price causes an accumulative decrease of 0.48 to $0.55 \%$ in wholesale gasoline prices, while simultaneously a $1 \%$ increase in the USD/PLN exchange rate leads to an accumulative increase of 0.68 to $0.77 \%$ in wholesale gasoline prices. A $1 \%$ appreciation of PLN versus USD leads to an accumulative decrease of 0.34 to $0.45 \%$ in wholesale gasoline prices. Therefore, even when NYH spot price falls but, at the same time, the local currency is depreciated, the net short-run impact on wholesale prices will be positive, of a magnitude of about $0.2 \%$. Similar short-run APT is observed for the future contract $\mathrm{Fl}$ (see table 4 and 5).

The last results of the examination focuses on an assessment of a speed asymmetry (B3) and visual check of price transmission's paths, as our research task is not only the APT examination, but also includes a comparison of pass-through patterns in a response to shifts in price determinants for two major players. Charts 3 to 8 in present dynamic multipliers both for permanent and for temporary changes in a particular regressor. We can observe a strong similarity between players in their short-term reactions to Brent crude changes, as well as in the speed of adjustment. For the NYH gasoline price transmission, we can see that both players show a significant dependency on that quotation, following a very similar pattern - which could be consistent with the focal price equilibrium of the strategic game showed in Bejger (2016a, pp. 294-298). For the USD/PLN exchange rate (in the model with the NYH gasoline price), evidence for similar long- and short-run downward asymmetry (speed and magnitude) is visible in the price paths of both players.

\section{Conclusion}

In this paper, a nonlinear autoregressive distributed lags model was implemented to empirically investigate the patterns in dynamic pass-through of important determinants of the wholesale gasoline price. We analyzed individual price data of the two major players (with a cumulative market share of 90\%) in the Polish market on a wholesale level of distribution, to examine possible APT, IPP pricing schema and to assess similarities in players' strategic behavior represented by their price reactions to shocks. Our examination revealed that:

the Import Parity Pricing mechanism of price creation seems to be confirmed, as the models with the NYH gasoline spot price proved to be superior versus models with Brent crude, and they were characterized by very similar dynamics of short- and long-run reactions in transmitting of the NYH gasoline price changes both for PKN and LOTOS. This suggests that the NYH spot price or a similar reference quotation could be a possible IPP factor. IPP pricing could force strong parallel price behaviour (enforced by focal price model) and there- 
fore foster tacit collusion, this result is consistent with both theoretical research and Competition Authorities' studies cited in section 1;

- there is significant short-run positive APT for the NYH spot price and future contract Fl;

- the most important factor in a hypothetical IPP mechanism of price creation is the USD/PLN exchange rate. There is significant 'rocket and feather' effect in transmission of the changes in that regressor, especially in a short run;

- short-run reaction patterns of the players exhibit some differences in transmission of changes in the USD/PLN exchange rate and the Brent crude price, but similarities in a general behaviour of price movements can be noticed. A delay in LOTOS reactions is visible versus PKN, but overall reactions of LOTOS are sharper. This observation drives us to a conclusion that both players have similar pricing schemas, including a quotation of the spot gasoline and the exchange rate, but short-term dynamics suggests that the exchange rate is included in those schemas in a slightly different manner;

- there are no positive APT effect in the rest of analysed potential wholesale price drivers.

For competition policy implications, the sensitivity of wholesale prices to changes in the USD/PLN exchange rate in a short-run can be emphasized, as well as clear positive asymmetry in pass-through when we take into account possible IPP benchmark prices like the NYH gasoline spot price or one month future contracts. It has a strong influence on the remaining part of the supply chain and on end consumers, when we consider the price creation mechanism functioning in the market. As Bagnai \& Ospina (2015, pp. 46-47) showed, this sensitivity is observed also for the EUR/USD exchange rate in the medium horizon (for monthly data). Similarly, Shin et al. (2013, pp. 30-33) showed that Korean gasoline prices are more sensitive to the exchange rate depreciations than to its appreciations. Our finding seems to confirm very clearly, using individual price series for the major players, that positive asymmetry of pass-through of shocks in USD/PLN exchange rate is a common pricing practice. This finding is consistent with the conclusion of Bagnai \& Ospina (2015, p. 49) that exchange rate swings are 'less clearly perceived', and therefore may encourage players to use 'rocket and feathers' pricing. The competition authorities should be aware of parallel pricing as well, which is more than possible due to focal role of a benchmark price. At first, 'basing-point pricing' is pointed in Posner (2001, pp. 79-93) as one of the plus factor facilitating collusion. At second, antitrust regulations treat parallel conduct as important indirect evidence of 'concerted practices', e.g. Section 1 of the Sherman Act, where phrase '<conscious commitment to a common scheme > is treated as covering also parallel conduct. Parallel pricing is also considered as so called "conduct evidence' (OECD, 2006, p. 21-23) or 'plus factor'. As the practical advice for a further market research, we would like to emphasize the importance of examination of the short-run reactions of downstream prices using daily data. Daily data are consistent with 
a price announcement scheme and allow to observe the most important asymmetries from the consumer's point of view. In a long-term perspective, majority of the fuel markets seem to be effective (symmetric), but an average consumer is mostly interested in a short term purchasing decisions.

\section{References}

Atil, A., Lahiani, A., \& Nguyen, D.K. (2014). Asymmetric and nonlinear passthrough of crude oil prices to gasoline and natural gas prices. Energy Policy, 65. doi:10.1016/j.enpol.2013.09.064.

Australian Competition and Consumer Commission. (2007). Petrol prices and Australian consumers: report of the ACCC inquiry into the price of unleaded petrol. Retrieved 11.09.2019 from https://www.accc.gov.au.

Bachmeier, L.J., \& Griffin, J.M. (2003). New evidence on asymmetric gasoline price responses. Review of Economics and Statistics, 85(3). doi:10.1162/003465303322369902.

Bacon, R.W. (1991). Rockets and feathers: the asymmetric speed of adjustment of UK retail gasoline prices to cost changes. Energy Economics, 13(3). doi:10.1016/0140-9883(91)90022-r.

Bagnai, A., \& Ospina, C.A.M. (2015). Long- and short-run price asymmetries and hysteresis in the Italian gasoline market. Energy Policy, 78. doi:10.1016/j. enpol.2014.12.017.

Balke, N.S., Brown, S.P.A., \& Yücel, M.K. (1998). Crude oil and gasoline prices: an asymmetric relationship? Economic and Financial Policy Review, 1.

Banerjee, A., Dolado, J., \& Mestre, R. (1998). Error-correction mechanism tests for cointegration in a single-equation framework. Journal of Time Series Analysis, 19(3). doi:10.1111/1467-9892.00091.

Bejger, S. (2015a). Investigation of the nature of strategic interactions in the Polish wholesale fuel market: statistical analysis of a market structure and a price mechanism. Acta Universitatis Nicolai Copernici Ekonomia, 46(1). doi:10.12775/aunc_econ.2015.003.

Bejger, S. (2015b). Screening for competition failures: some remarks on horizontal anticompetitive behavior visual detection. Ekonomia i Prawo. Economics and Law, 14(2). doi:10.12775/eip.2015.010.

Bejger, S. (2016a). Theoretical model of pricing behavior on the Polish wholesale fuel market. Folia Oeconomica Stetinensia, 16(1). doi:10.1515/foli-2016-0019.

Bejger, S. (2016b). Wykrywanie, pomiar i ocena strategicznych, horyzontalnych zachowań niekonkurencyjnych przedsiębiorstw: analiza ilościowa. Toruń: UMK.

Bejger, S., \& Bruzda, J. (2002). Identification of market power using test for asymmetric pricing: an example of Polish petrochemical industry. Dynamic Econometric Models, 5.

Borenstein, S. (1991). Selling costs and switching costs: explaining retail gasoline margins. RAND Journal of Economics, 22(3). doi:10.2307/2601052. 
Borenstein, S., \& Shepard, A. (2002). Sticky prices, inventories, and market power in wholesale gasoline markets. RAND Journal of Economics, 33(1). doi:10.2307/2696378.

Borenstein, S., Cameron, A.C., \& Gilbert, R. (1997). Do gasoline prices respond asymmetrically to crude oil price changes? Quarterly Journal of Economics, 112(1). doi:10.1162/003355397555118.

Bundeskartellamt. (2009). Fuel sector inquiry. Retrieved 11.09.2019 from https://www.bundeskartellamt.de.

Bundeskartellamt. (2011). Fuel sector inquiry. Retrieved 11.09.2019 from https:// www.bundeskartellamt.de.

Chattopadhyay, M., \& Mitra, S.K. (2015). Exploring asymmetric behavior pattern from Indian oil products prices using NARDL and GHSOM approaches. Energy Policy, 86. doi:10.1016/j.enpol.2015.06.035.

Consolidated versions of the Treaty on European Union and the Treaty on the Functioning of the European Union (OJ C 326 2012/C 326/01).

Enders, W., \& Granger, C.W.J. (1998). Unit root tests and symmetric adjustment with an example using the term structure of interest rates. Journal of Business and Economic Statistics, 16(3). doi:10.1080/07350015.1998.1052 4769.

Energy Information Administration. (2014). What drives U.S. gasoline prices? Retrieved 11.09.2019 from https://www.eia.gov.

Faber, R.P., \& Janssen, M.C.W. (2019). On the effects of suggested prices in gasoline markets. Scandinavian Journal of Economics, 121(2). doi:10.1111/ sjoe.12289.

Frey,G., \&Manera,M.(2007). Econometricmodels ofasymmetricpricetransmission. JournalofEconomicSurveys, 21(2). doi:10.1111/j.1467-6419.2007.00507.x.

Friedman, J.W. (1971). A non-cooperative equlibrium for supergames. Review of Economic Studies, 38(1). doi:10.2307/2296617.

Granger, C.W.J., \& Lee, T.H. (1989). Investigation of production, sales and inventory relationships using multicointegration and non-symmetric error correction models. Journal of Applied Econometrics, 4(S1). doi:10.1002/ jae.3950040508.

Greenwood-Nimmo, M., \& Shin, Y. (2013). Taxation and the asymmetric adjustment of selected retail energy prices in the UK. Economics Letters, 121(3). doi:10.1016/j.econlet.2013.09.020.

Hansen, B.E. (2000). Sample splitting and threshold estimation. Econometrica, 68(3). doi:10.1111/1468-0262.00124.

Johnson, R.N. (2002). Search costs, lags and prices at the pump. Review of Industrial Organization, 20(1). doi:10.1023/A:1013364513064.

Judgment of the European Court (1993). A. Ahlström Osakeyhtiö and others v Commission of the European Communities (ECRI 1993-01307).

Judgment of the European Court. (1972). Imperial Chemical Industries Ltd. v Commission of the European Communities (ECR 1972-00619). 
Judgment of the European Court. (1975). Coöperatieve Vereniging „Suiker Unie" UA and others v Commission of the European Communities (ECR 1975-01663).

Karagiannis, S., Panagopoulos, Y., \& Vlamis, P. (2015). Are unleaded gasoline and diesel price adjustments symmetric? A comparison of the four largest EU retail fuel markets. Economic Modelling, 48. doi:10.1016/j.econmod.2014.11.003.

Kaufmann, R.K., \& Laskowski, C. (2005).Causes for an asymmetric relation between the price of crude oil and refined petroleum product. Energy Policy, 33(12). doi:10.1016/j.enpol.2004.01.013.

Kwiatkowski, D., Phillips, P.C.B., Schmidt, P., \& Shin, Y. (1992). Testing the null hypothesis of stationary against the alternative of a unit root. Journal of Econometrics, 54(1-3). doi:10.1016/0304-4076(92)90104-y.

Leszkiewicz-Kędzior, K. (2011). Modelling fuel prices: an I(1) analysis. Central European Journal of Economic Modelling and Econometrics, 3(2). doi:10.24425/ cejeme.2011.119305.

Leszkiewicz-Kędzior, K., \& Welfe, A. (2014). Asymmetric price adjustments in the fuel market. Central European Journal of Economic Modelling and Econometrics, 6(2). doi:10.24425/cejeme.2014.119235.

MacKinnon, J.G. (1996). Numerical distribution functions for unit root and cointe-gration tests. Journal of Applied Econometrics, 11(6).

Maskin, E., \& Tirole, J. (1988). A theory of dynamic oligopoly II. Econometrica, 57(6). doi:10.2307/1913726.

Meyer, J., \& Cramon-Taubadel, S. (2004). Asymmetric price transmission: a survey. Journal of Agricultural Economics, 55(3). doi:10.1111/j.1477-9552.2004. tb00116.x.

Miłobędzki, P. (2008). Orlen or Lotos? Which is setting prices at the wholesale market for unleaded petrol in Poland? Dynamic Econometric Models, 8.

OECD. (2006). Prosecuting cartels without direct evidence of agreement. Retrieved 11.09.2019 from http://www.oecd.org.

OECD. (2013). Competition in road fuel. Retrieved 11.09.2019 from http://www. oecd.org.

Peltzman, S. (2000). Prices rise faster than they fall. Journal of Political Economy, 108(3). doi:10.1086/262126.

Perdiguero-García, J. (2013). Symmetric or asymmetric oil prices? A meta-analysis approach. Energy Policy, 57. doi:10.1016/j.enpol.2013.02.008.

Perron, P. (1989). The great crash, the oil price shock, and the unit root hypothesis. Econometrica, 57(6). doi:10.2307/1913712.

Pesaran, H.M., Shin, Y.C., \& Smith, J.R. (2001). Bounds testing approaches to the analysis of level relationships. Journal of Applied Econometrics, 16(3). doi:10.1002/jae.616. 
Pesaran, M.H., \& Shin, Y. (1999). An autoregressive distributed lag modelling approach to cointegration analysis. In S. Strom (Ed.), Econometrics and economic theory in the 20th century: the Ragnar Frisch centennial symposium. Cambridge: Cambridge University Press.

Polish Oil Industry and Trade Organisation. (2016). The Polish Oil Industry and Trade Organisation annual report. Retrieved 11.09.2019 from http:// www.popihn.pl.

Polish Oil Industry and Trade Organisation. (2017). The Polish Oil Industry And Trade Organisation annual report. Retrieved 11.09.2019 from http://www. popihn.pl.

Portuguese Competition Authority. (2009). Detailed analysis of the liquid fuel and bottled gas sectors in Portugal. Retrieved 11.09.2019 from http://www. concorrencia.pt.

Posner, R.A. (2001). Antitrust Law. Chicago: University of Chicago Press.

Pöyry Energy Consulting (2009). Survey of the competitive aspects of oil and oil product markets in the EU: a report to Directorate-General Energy and Transport of the European Commission. Retrieved 11.09.2019 from http://ec.europa.eu.

Radchenko, S. (2005). Oil price volatility and the asymmetric response of gasoline prices to oil price increases and decreases. Energy Economics, 27(5). doi:10.1016/j.eneco.2005.06.001.

Shin, Y., Yu, B., \& Greenwood-Nimmo, M.J. (2013). Modelling asymmetric cointegration and dynamic multipliers in a nonlinear ARDL framework. In W.C. Horrace, \& R.C. Sickles (Eds.), Festschrift in honor of Peter Schmidt : econometric methods and applications. New York: Springer.

\section{Acknowledgements}

Author contributions: author has given an approval to the final version of the article.

Funding: this research was funded by the Nicolaus Copernicus University of Torun, Faculty of Economic Sciences and Management statutory sources.

Note: the results of this study were presented at 15th Professor Zygmunt Zielinski International Conference on Dynamic Econometric Models (September 5-9, 2017, Toruń, Poland). 


\section{Appendix}

Table 1.

Descriptive statistics

\begin{tabular}{lrrrrrrrrr}
\hline \multicolumn{1}{c}{ Specification } & lw_p_n & lw_ln$n$ & \multicolumn{1}{c}{$l b_{-} s$} & \multicolumn{1}{c}{ lnyh_s } & \multicolumn{1}{c}{ lus_x } & \multicolumn{1}{c}{ lf_l } & \multicolumn{1}{c}{ lf_2 } & \multicolumn{1}{c}{ lf_3 } & lf_4 \\
\hline mean & 7.57 & 7.57 & 6.19 & 6.32 & 1.14 & 6.34 & 6.34 & 6.34 & 6.34 \\
median & 7.53 & 7.53 & 6.20 & 6.35 & 1.14 & 6.37 & 6.36 & 6.35 & 6.34 \\
maximum & 8.04 & 8.04 & 6.81 & 6.88 & 1.45 & 6.85 & 6.85 & 6.84 & 6.83 \\
minimum & 6.65 & 6.66 & 5.10 & 5.34 & 0.70 & 5.34 & 5.40 & 5.45 & 5.60 \\
standard deviation & 0.25 & 0.25 & 0.35 & 0.30 & 0.14 & 0.30 & 0.29 & 0.28 & 0.27 \\
skewness & -0.26 & -0.24 & -0.48 & -0.51 & -0.37 & -0.53 & -0.46 & -0.40 & -0.36 \\
kurtosis & 2.79 & 2.75 & 2.25 & 2.38 & 3.47 & 2.45 & 2.31 & 2.19 & 2.07 \\
Jarque-Bera & 36.84 & 34.5 & 179.50 & 169.56 & 90.42 & 169.68 & 157.38 & 156.74 & 165.50 \\
observations & 2870 & 2870 & 2870 & 2870 & 2870 & 2870 & 2870 & 2870 & 2870 \\
\hline
\end{tabular}

Source: Own preparation.

Table 2.

ADF test results: levels and first differences

\begin{tabular}{|c|c|c|c|}
\hline Series & Probability* & Series & Probability* \\
\hline$l w \_p \_n$ & 0.1462 & $\Delta\left(l w_{-} p_{-} n\right)$ & 0.0000 \\
\hline$l w_{-} l \_n$ & 0.2199 & $\Delta\left(l w \_l \_n\right)$ & 0.0000 \\
\hline$l b \_s$ & 0.5108 & $\Delta\left(l b \_s\right)$ & 0.0001 \\
\hline lnyh_s & 0.1963 & $\Delta($ lnyh_s $)$ & 0.0001 \\
\hline lus_x & 0.6701 & $\Delta\left(l u s \_x\right)$ & 0.0001 \\
\hline$l f \_l$ & 0.2361 & $\Delta\left(l f \_l\right)$ & 0.0001 \\
\hline lf_2 & 0.2848 & $\Delta\left(l_{-} 2\right)$ & 0.0001 \\
\hline lf 3 & 0.3098 & $\Delta\left(l_{-} 3\right)$ & 0.0001 \\
\hline lf_4 & 0.2681 & $\Delta\left(l_{-} 4\right)$ & 0.0001 \\
\hline
\end{tabular}

Notes:

* MacKinnon (1996) one-sided p-values.

Source: Own preparation. 
Table 3.

KPSS test statistics

\begin{tabular}{|c|c|c|}
\hline Series & Level & First differences \\
\hline$l w_{-} p_{-} n$ & 2.524 & 0.062 \\
\hline$l w \_l \_n$ & 2.517 & 0.058 \\
\hline$l b_{-} s$ & 0.968 & 0.156 \\
\hline lnyh_s & 0.791 & 0.079 \\
\hline lus_x & 3.518 & 0.156 \\
\hline lf_l & 0.767 & 0.085 \\
\hline lf_2 & 0.782 & 0.090 \\
\hline lf_3 & 0.810 & 0.089 \\
\hline lf_4 & 0.832 & 0.073 \\
\hline
\end{tabular}

Notes:

Asymptotic critical values: 0.739 (1\%) 0.463 (5\%) 0.347 (10\%) by Kwiatkowski et al. (1992).

Source: Own preparation.

Table 4.

NARDL estimation results

\begin{tabular}{|c|c|c|c|c|c|c|}
\hline \multirow{4}{*}{$\begin{array}{l}\text { dependent variable } \\
\text { regressor } x \\
\text { model estimated } \\
\text { parameter }\end{array}$} & \multicolumn{3}{|c|}{$l w_{-} p_{-} n$} & \multicolumn{3}{|c|}{$l w \_l \_n$} \\
\hline & \multicolumn{3}{|c|}{$l b_{-} s$} & \multicolumn{3}{|c|}{$l b \_s$} \\
\hline & \multicolumn{3}{|c|}{$\operatorname{ARDL}(6,6,6,5,6)$} & \multicolumn{3}{|c|}{$\operatorname{ARDL}(6,6,6,4,6)$} \\
\hline & value & t-statistic & probability & value & t-statistic & probability \\
\hline \multirow[t]{3}{*}{$\rho$} & -0.0199 & -6.4941 & 0.0000 & -0.0216 & -6.5110 & 0.0000 \\
\hline & 1.1331 & 7.1157 & 0.0000 & 1.0863 & 7.4920 & 0.0000 \\
\hline & 1.1545 & 8.2184 & 0.0000 & 1.1167 & 8.7379 & 0.0000 \\
\hline $\boldsymbol{\Phi}_{j}^{+}$ & 0.8491 & 12.2630 & 0.0000 & 0.8293 & 11.7410 & 0.0000 \\
\hline $\boldsymbol{\Phi}_{j}^{-}$ & 0.8379 & 11.2800 & 0.0000 & 0.8143 & 10.8430 & 0.0000 \\
\hline \multirow[t]{2}{*}{$\sigma_{\varepsilon}^{2}$} & 0.1787 & 5.3848 & 0.0000 & 0.1628 & 4.5783 & 0.0000 \\
\hline & 0.2229 & 7.5059 & 0.0000 & 0.1773 & 5.5838 & 0.0000 \\
\hline \multirow{2}{*}{ 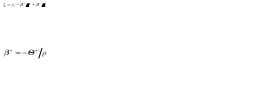 } & 0.1136 & 8.0991 & 0.0000 & 0.1144 & 7.5980 & 0.0000 \\
\hline & 0.1679 & 12.2040 & 0.0000 & 0.1403 & 9.5184 & 0.0000 \\
\hline cointagration tests & \multicolumn{3}{|c|}{ statistic value } & \multicolumn{3}{|c|}{ statistic value } \\
\hline$f_{-} p s s$ & \multicolumn{3}{|c|}{8.6584} & \multicolumn{3}{|c|}{8.6902} \\
\hline t_bdm & \multicolumn{3}{|c|}{-6.4941} & \multicolumn{3}{|c|}{-6.5110} \\
\hline symmetry restrictions* & \multicolumn{2}{|l|}{ statistic value } & probability & \multicolumn{2}{|c|}{$\begin{array}{l}\text { statistic value } \\
\end{array}$} & probability \\
\hline$w_{-} l r_{-} u$ & \multicolumn{2}{|l|}{-0.6573} & 0.5110 & \multicolumn{2}{|c|}{-0.8557} & 0.3922 \\
\hline$w_{-} l r_{-} x$ & \multicolumn{2}{|l|}{0.7351} & 0.4623 & \multicolumn{2}{|c|}{0.8872} & 0.3750 \\
\hline$w \_s r p w \_x$ & \multicolumn{2}{|l|}{1.5210} & 0.1670 & \multicolumn{2}{|c|}{4.3844} & 0.0002 \\
\hline w_sra_u & \multicolumn{2}{|l|}{0.4849} & 0.6277 & \multicolumn{2}{|c|}{0.3331} & 0.7390 \\
\hline$w_{-} s r a \_x$ & \multicolumn{2}{|l|}{2.2546} & 0.0242 & \multicolumn{2}{|c|}{1.8467} & 0.0649 \\
\hline w_sri_u & \multicolumn{2}{|l|}{-0.7445} & 0.4566 & \multicolumn{2}{|c|}{-0.2579} & 0.7965 \\
\hline w_sri_x & \multicolumn{2}{|l|}{-1.6105} & 0.1074 & \multicolumn{2}{|c|}{-1.0438} & 0.2966 \\
\hline
\end{tabular}




\begin{tabular}{lcrrr}
\hline \multicolumn{1}{c}{ diagnostics } & statistic value & probability & statistic value & probability \\
\hline BG serial correlation test & 0.4799 & 0.6962 & 1.7191 & 0.1609 \\
Ramsey RESET Test & 1.0746 & 0.3000 & 0.2512 & 0.6163 \\
adjusted R-squared & 0.4011 & - & 0.3874 & - \\
Akaike criterion & -6.6832 & - & -6.5453 & - \\
\hline
\end{tabular}

Table 4. (cont.)

\section{NARDL estimation results}

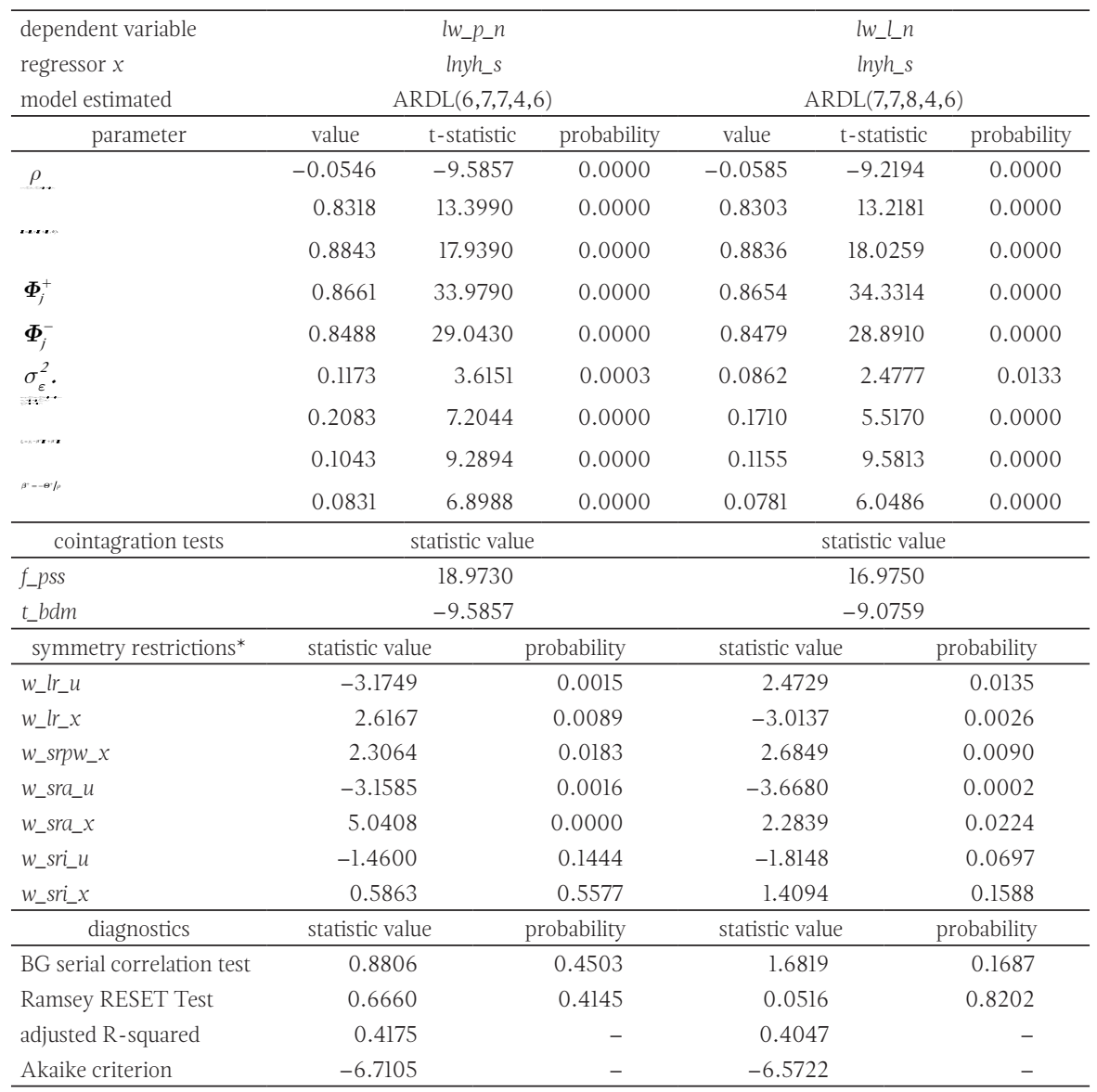


Table 4. (cont.)

NARDL estimation results

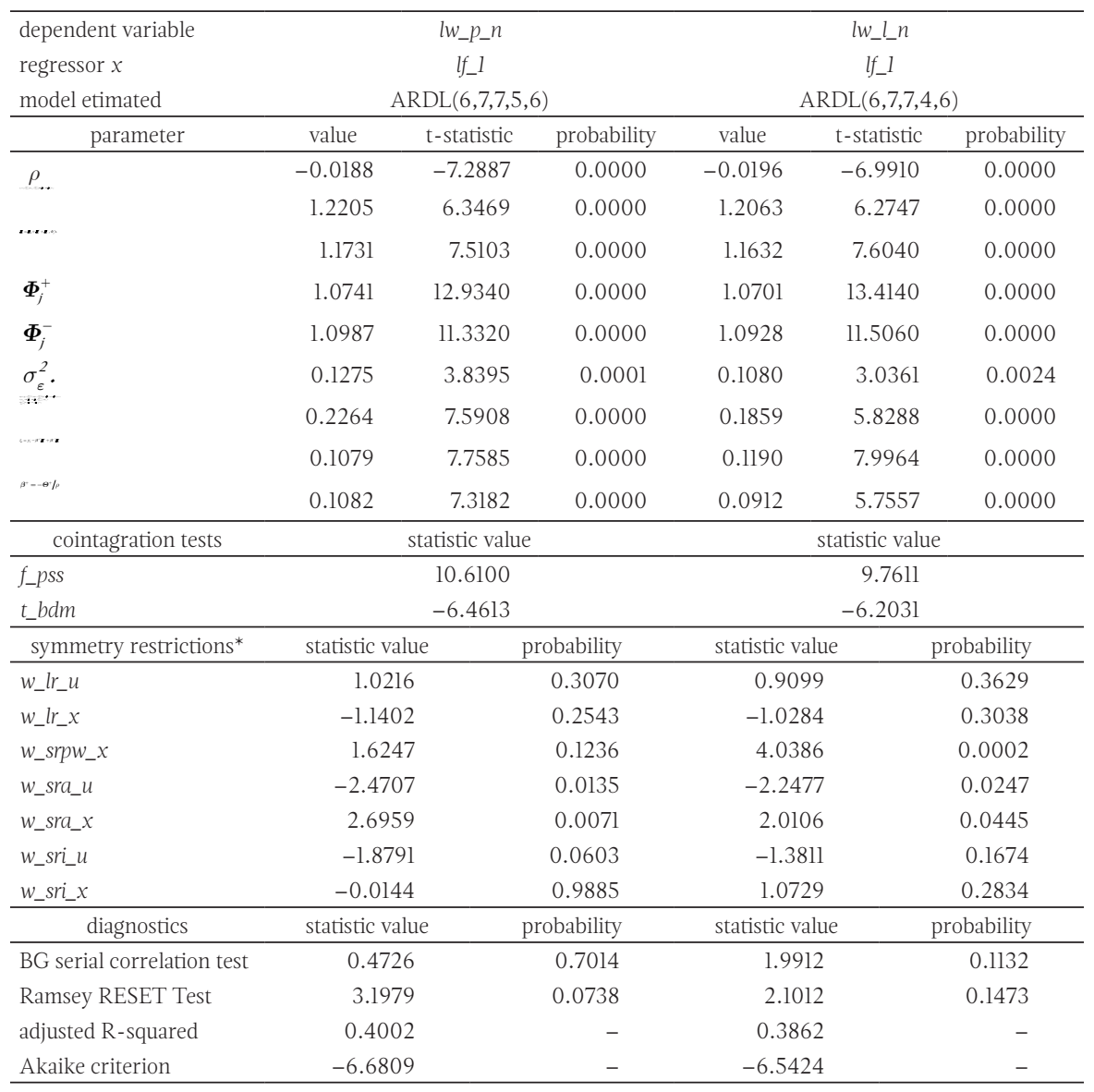

Notes:

$f_{-} p s s, t \_b d m$ : F-statistics of $f_{-} p s s$ and $t$-statistics of $t \_b d m$ bound testing approach, the critical values for Case 3 unrestricted intercept and no trend, $k=4$ and usual significance levels:

\begin{tabular}{lllccc}
\hline F-statistic & $\mathrm{I}(0)$ & $\mathrm{I}(1)$ & t-statistic & $\mathrm{I}(0)$ & $\mathrm{I}(\mathrm{l})$ \\
\hline $1 \%$ & 3.74 & 5.06 & $1 \%$ & -3.43 & -4.60 \\
$5 \%$ & 2.86 & 4.01 & $5 \%$ & -2.86 & -3.99 \\
$10 \%$ & 2.45 & 3.52 & $10 \%$ & -2.57 & -3.66 \\
\hline
\end{tabular}

*For various Symmetry restrictions hypothesis values of a Wald test t-statistics (F-statistc in case of $w_{-}$ $s r_{-} p w_{-} x$ ) are reported. Values significant at usual level (at most 10\%) are framed.

Source: Own preparation. 
Table 5.

Aggregates of significant positive and negative short-run multipliers: additive asymmetry cases

\begin{tabular}{|c|c|c|c|c|c|c|}
\hline Dependent variable & $l w_{-} p_{-} n$ & $l w_{-} l \_n$ & $l w_{-} p_{-} n$ & $l w_{-} l \_n$ & $l w_{-} p_{-} n$ & $l w \_l n$ \\
\hline Regressor $x$ & $l b \_s$ & $l b \_s$ & lnyh_s & lnyh_s & lf_l & lf_l \\
\hline $\boldsymbol{\beta}^{-}=-\boldsymbol{\Theta}^{-} / \rho$ & - & - & 0.3449 & 0.4547 & 0.5235 & 0.6254 \\
\hline-+ & - & - & 0.6784 & 0.7687 & 0.7562 & 0.8425 \\
\hline- & 0.4916 & 0.5199 & 0.4797 & 0.5455 & 0.5749 & 0.6004 \\
\hline$\Delta x^{+}$ & 0.3826 & 0.4315 & 0.3536 & 0.4412 & 0.4344 & 0.5166 \\
\hline
\end{tabular}

Source: Own preparation.

\section{Chart 1.}

Domestic production and consumption of liquid fuels in Poland: volume (in thousand of cubic meters, on left) and structure (in \%, on right) in 2016

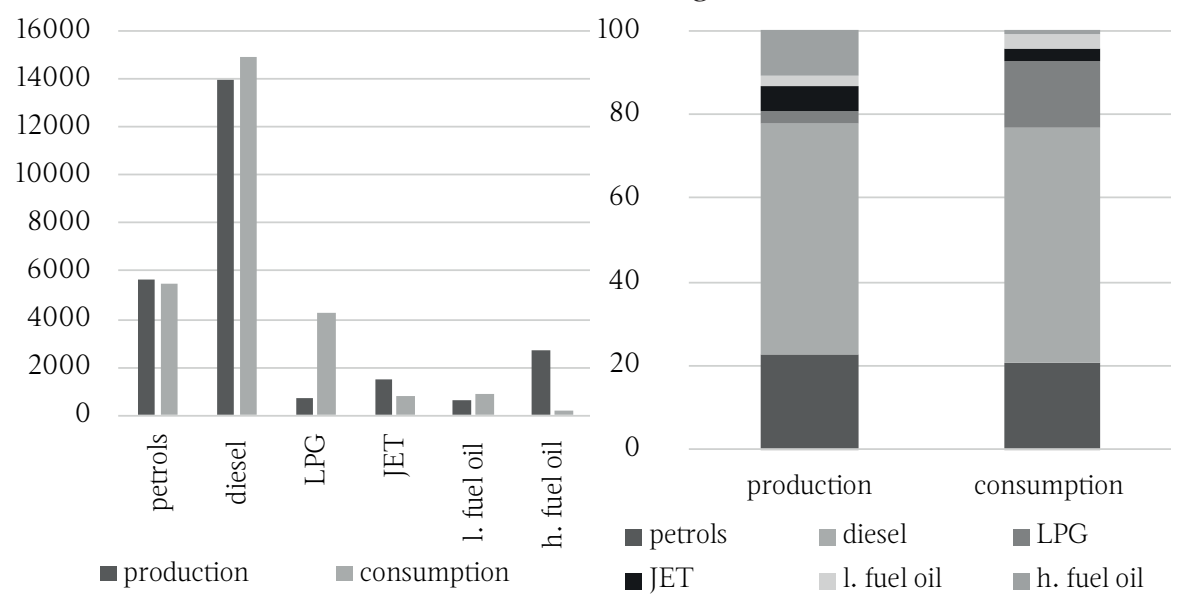

Source: Own preparation. 


\section{Chart 2.}

Major players: wholesale market shares (motor fuels and light heating oil, on left) and crude processing (in mln tonnes, on right)
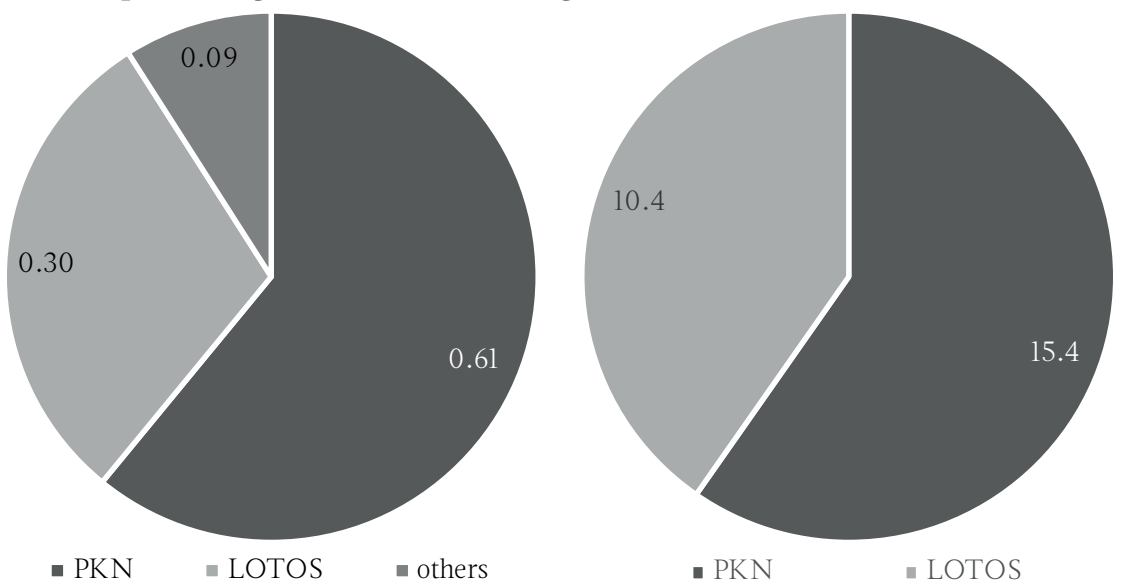

Notes:

As detailed data on volumes of fuels sold at the wholesale level are not publically available, the market shares are estimated on a basis of the Polish Oil Industry and Trade Organisation $(2016,2017)$ annual reports and crude processing.

Source: Own preparation. 


\section{Chart 3.}

\section{Cumulative dynamic multipliers, Brent crude, USD/PLN (permanent change)}

PKN wholesale price response to $1 \%$ change

$1 \quad$ in price of Brent crude oil

0

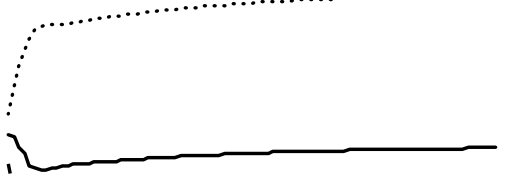

1

1

$-1$

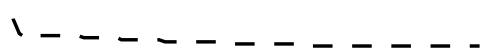

-1 $1 \quad 81522293643505764717885$

- difference

- - response to negative change

...... response to positive change

PKN wholesale price response to $1 \%$ change

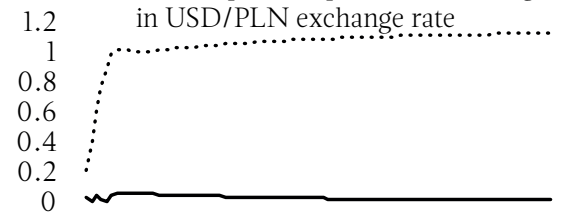

-0.2 ,

$-0.4$

$-0.6$

$-0.8$

$-1$

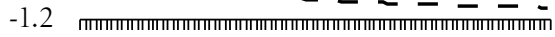

181522293643505764717885

- difference

- - response to negative change

...... response to positive change
LOTOS wholesale price response to $1 \%$ change

$1 \quad$ in price of Brent crude oil

0

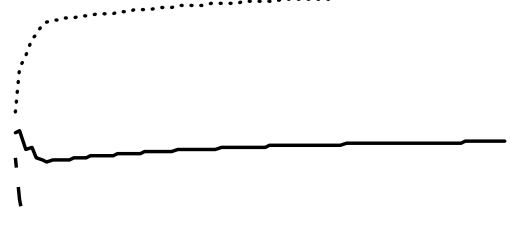

-1

171319253137434955616773798591

- difference

- - response to negative change

...... response to positive change

LOTOS wholesale price response to $1 \%$ change

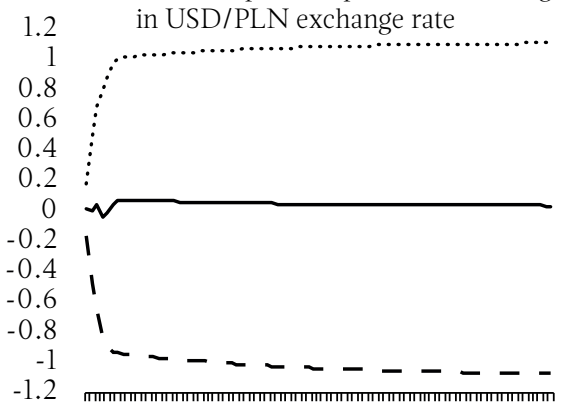

181522293643505764717885

- difference

- - response to negative change

...... response to positive change

Notes:

The dashed (dotted) line is the cumulative dynamic multiplier with respect to a $1 \%$ negative (positive) change in the Brent crude oil price (USD/PLN exch. rate) while solid line plots the difference between the two. Tick marks on the horizontal axis represent 90 day intervals while the vertical axis is in percentage points.

Source: Own preparation. 


\section{Chart 4.}

\section{Dynamic multipliers, Brent crude, USD/PLN, (temporary change)}

PKN wholesale price response to $1 \%$ temporary changein price of Brent crude oil

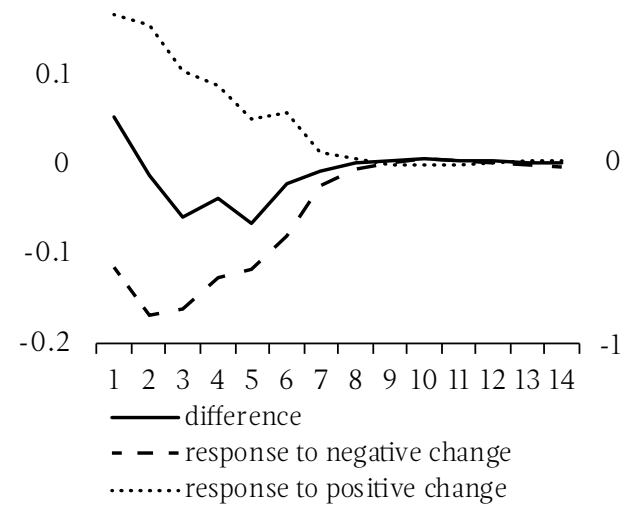

PKN wholesale price response to $1 \%$ temporary change in USD/PLN exchange rate

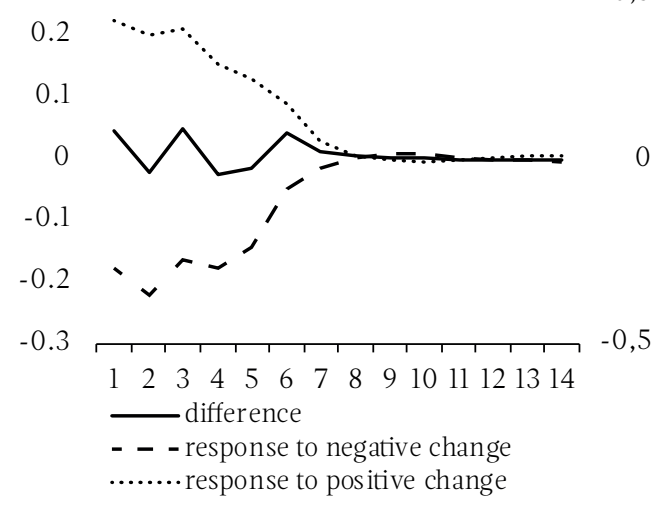

LOTOS wholesale price response to $1 \%$ 1 temporary changein price of Brent crude oil
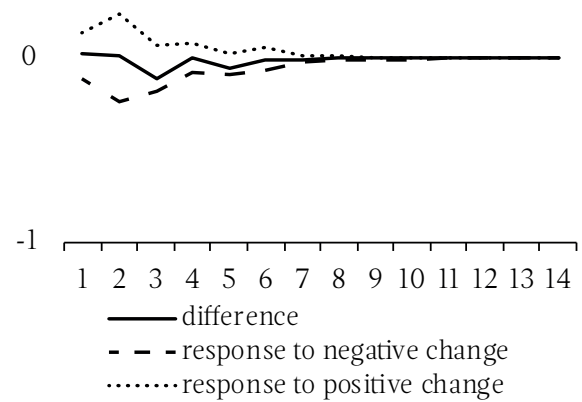

LOTOS wholesale price response to $1 \%$ $\underset{0,5}{\text { temporary change in USD/PLN exchange rate }}$
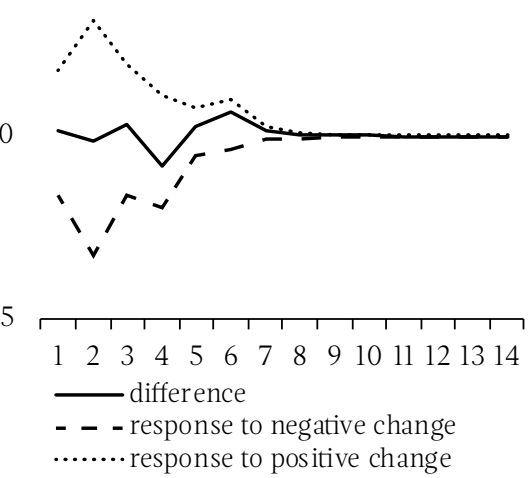

Notes:

The dashed (dotted) line is the dynamic multiplier with respect to a $1 \%$ negative (positive) temporary change in the Brent crude oil price (USD/PLN exch. rate) while solid line plots the difference between the two. Tick marks on the horizontal axis represent 14 day intervals while the vertical axis is in percentage points.

Source: Own preparation. 


\section{Chart 5.}

\section{Cumulative dynamic multipliers, NYH, USD/PLN, (permanent change)}

PKN wholesale price response to $1 \%$

1

0

change in price of NYH gasoline

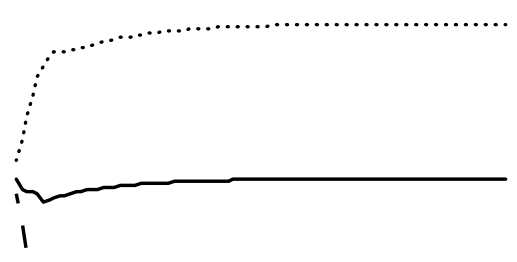
171319253137434955616773798591

- difference

- - - response to negative change

....... response to positive change

PKN wholesale price response to $1 \%$

1.2 change in USD/PLN exchange rate

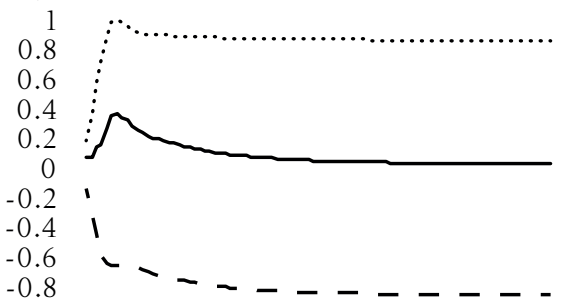

$-1$

$-1.2$
LOTOS wholesale price response to $1 \%$ change in price of NYH gasoline

0

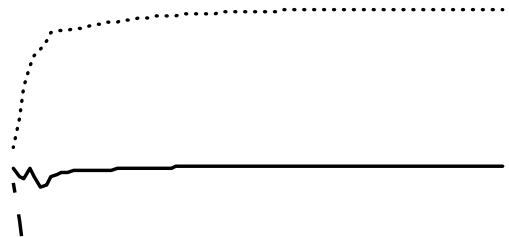

1

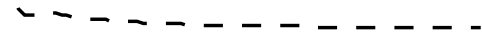

-1 171319253137434955616773798591

- difference

- - - response to negative change

…... response to positive change

LOTOS wholesale price response to $1 \%$

1.2 change in USD/PLN exchange rate

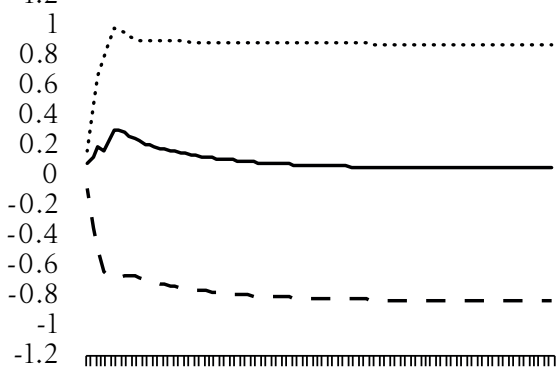

181522293643505764717885

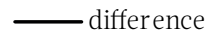

- - - response to negative change

....... response to positive change

Notes:

The dashed (dotted) line is the cumulative dynamic multiplier with respect to a $1 \%$ negative (positive) change in the NYH gasoline spot price (USD/PLN exch. rate) while solid line plots the difference between the two. Tick marks on the horizontal axis represent 90 day intervals while the vertical axis is in percentage points.

Source: Own preparation. 


\section{Chart 6.}

\section{Dynamic multipliers, NYH gasoline, USD/PLN, (temporary change)}

PKN wholesale price response to $1 \%$ temporary change in price of NYH gasoline

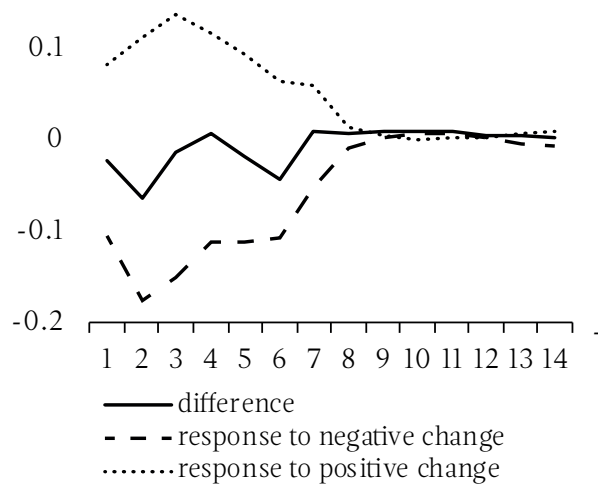

PKN wholesale price response to $1 \%$ temporary change in USD/PLN exchange rate 0.5

0

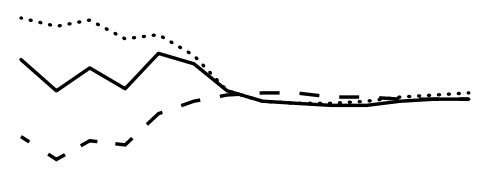

LOTOS wholesale price response to $1 \%$ 0.25 temporary change in price of NYH gasoline

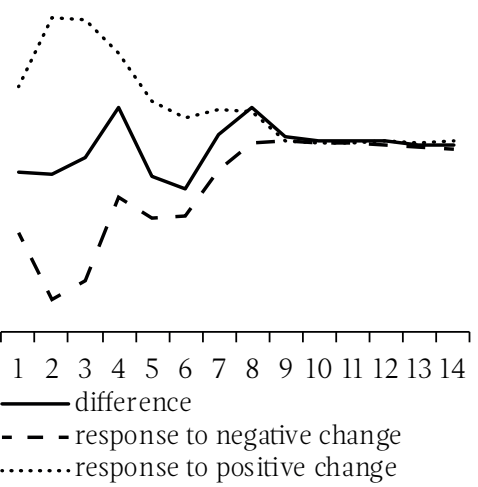

LOTOS wholesale price response to $1 \%$ temporary change in USD/PLN exchange rate 0.5

0

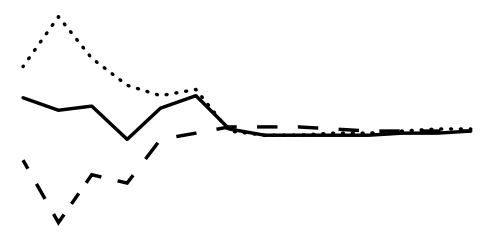

\section{$-0.5$ \\ $\begin{array}{llllllllllllll}1 & 2 & 3 & 4 & 5 & 6 & 7 & 8 & 9 & 1011 & 121314\end{array}$ \\ difference \\ - - - response to negative change \\ ........ response to positive change}

$-0.5$

$\begin{array}{lllllllllllllll}1 & 2 & 3 & 4 & 5 & 6 & 7 & 8 & 9 & 1011 & 1213 & 14\end{array}$

- difference

- - - response to negative change

........ response to positive change

Notes:

The dashed (dotted) line is the dynamic multiplier with respect to a $1 \%$ negative (positive) temporary change in the NYH gasoline spot price (USD/PLN exch. rate) while solid line plots the difference between the two. Tick marks on the horizontal axis represent 14 day intervals while the vertical axis is in percentage points.

Source: Own preparation. 


\section{Chart 7.}

\section{Dynamic multipliers, Fl future contract (permanent and temporary change)}

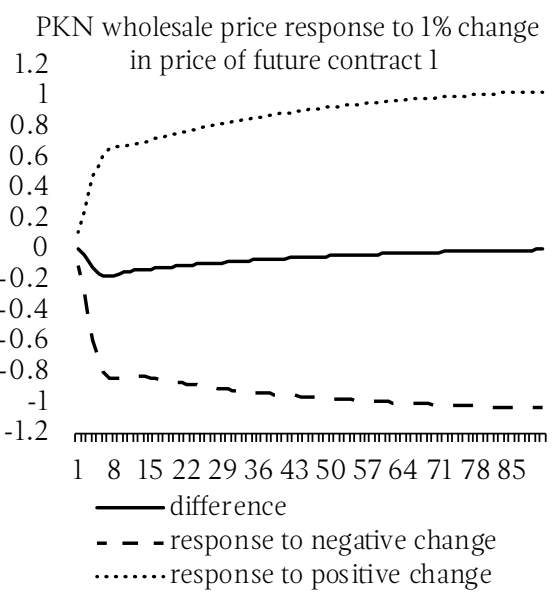

PKN wholesale price response to $1 \%$ temporary change in price of future contract 1 0.2

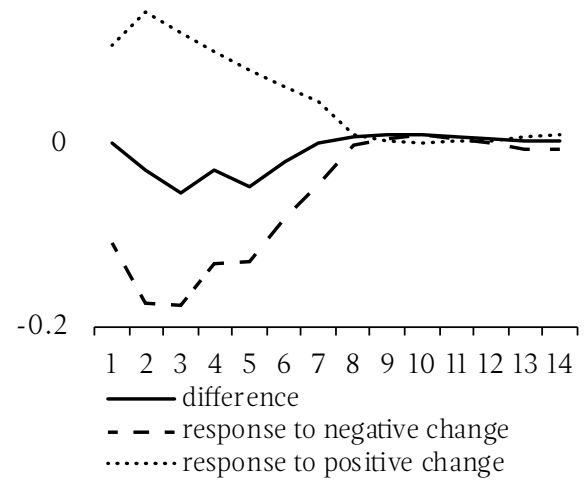

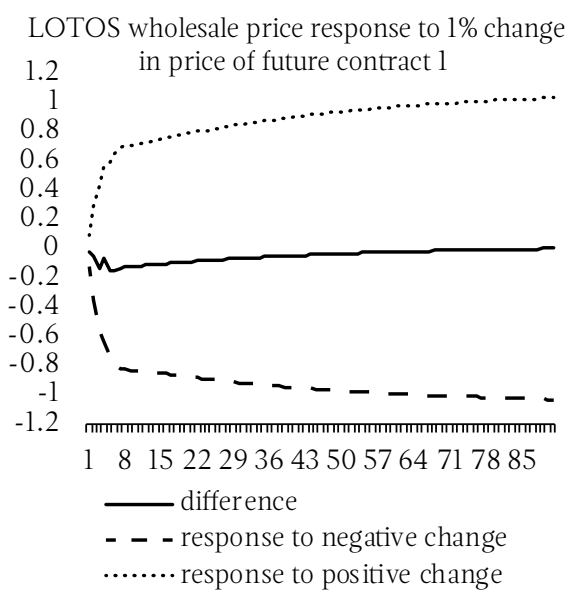

LOTOS wholesale price response to $1 \%$ temporary change in price of future contract 1 0.5

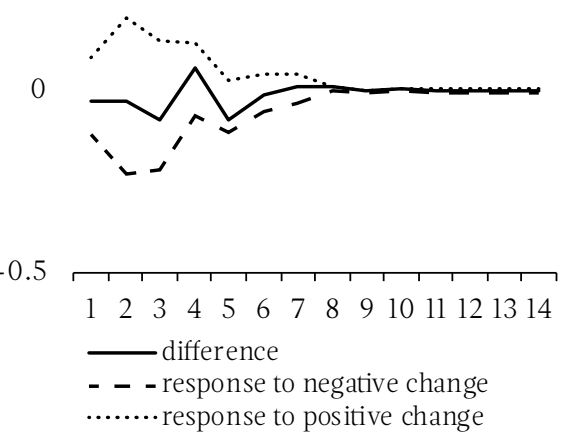

Notes:

The dashed (dotted) line is the dynamic multiplier with respect to a $1 \%$ negative (positive) change in the Fl contract while solid line plots the difference between the two. Tick marks on the horizontal axis represent 90 and 14 day intervals while the vertical axis is in percentage points.

Source: Own preparation. 


\section{Chart 8.}

Dynamic multipliers, USD/PLN exchange rate, Fl future contract (permanent and temporary change)

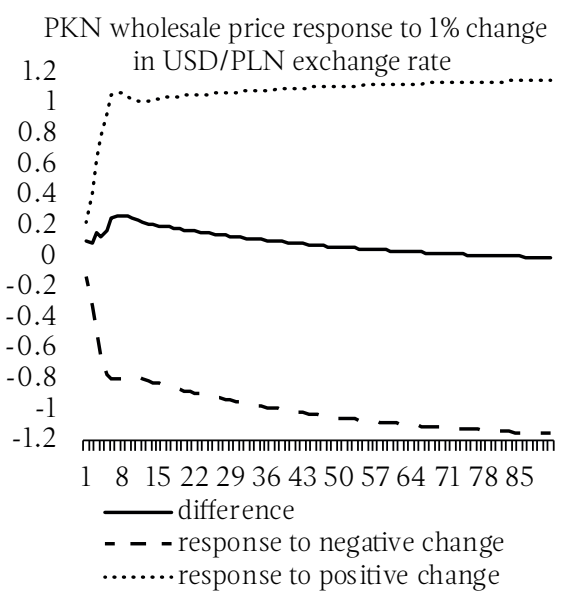

PKN wholesale price response to $1 \%$ temporary change in USD/PLN exchange rate 0.5

0

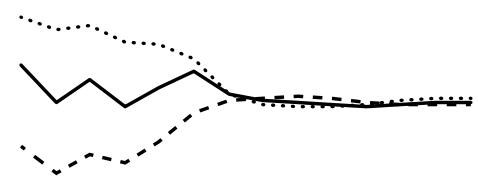

LOTOS wholesale price response to $1 \%$ change

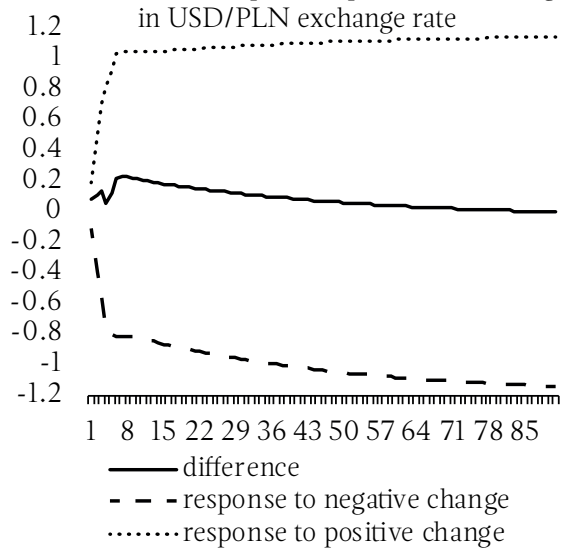

LOTOS wholesale price response to $1 \%$ temporary change in USD/PLN exchange rate 0.5

0

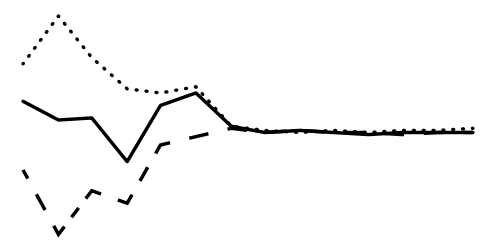

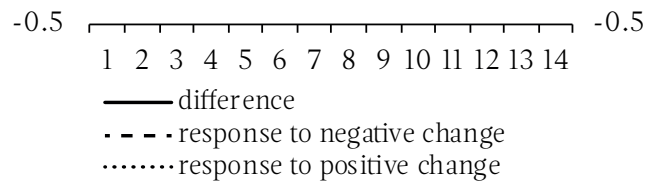

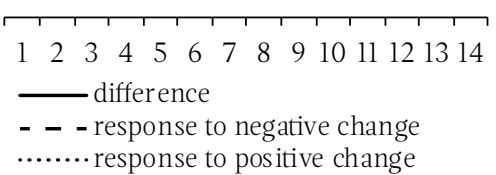

Notes:

The dashed (dotted) line is the dynamic multiplier with respect to a $1 \%$ negative (positive) change in the USD/PLN exchange rate while solid line plots the difference between the two. Tick marks on the horizontal axis represent 90 and 14 day intervals while the vertical axis is in percentage points.

Source: Own preparation. 